\title{
Miłosz, wojna i poezja cywilna
}

\section{Irena Grudzińska-Gross}

Podczas konferencji celebrujących stulecie urodzin Czesława Miłosza wielokrotnie wracała kwestia jego wyborów i zachowań podczas drugiej wojny światowej. Trzy tematy dominowały w tych dyskusjach: stosunek Miłosza do Zagłady, do powstania warszawskiego i do poetów ultranacjonalistycznego miesięcznika „Sztuka i Naród”, wydawanego w Warszawie od roku 1942 do powstania warszawskiego. Tematy te są, oczywiście, ze sobą powiązane. Choć ton wypowiedzi, które słyszałam, był zazwyczaj Miłoszowi sprzyjający, nie obyło się bez stwierdzeń, a nawet całych referatów, bardzo wobec niego krytycznych. Jedną z takich wypowiedzi był referat prof. Stanisława Beresia zatytułowany Cierń konspiracji1 ${ }^{1}$. Stanowić będzie punkt wyjścia moich rozważań, bo Bereś, powołując się na Zbigniewa Herberta, kontynuuje najważniejszą polską dyskusję światopoglądową dotyczącą zachowań w czasach wojny. Chodzi o postawę cywilną Miłosza, o jego krytykę poetów „Sztuki i Narodu”, a nawet o jego prawo do unikania walki zbrojnej i do krytykowania zmarłych. Chodzi o to, czy żywi mogą nazwać faszystą polskiego faszystę, który poległ zabity przez okupanta². Chodzi o prawo głosu osoby cywilnej.

Zacznę od paru słów na temat referatu Stanisława Beresia. Miłosz, jego zdaniem, w „półwiekowym spektaklu nienawiści” i z „zajadłą nieustępliwością” „przez 60 lat napada na kilku młodych poetów, którzy poginęli w wieku 20 lat z rąk niemieckich okupantów". Wypowiedzi poety na temat młodych poległych Bereś nazywa „bombardowaniem”, a milczenie o nich - „wyparciem”. Swój własny atak Bereś opiera na specjalnej interpretacji słów samego Miłosza. Po drobiazgowym podliczeniu wszystkich wzmianek o młodych poetach i statystycznym opracowaniu temperatury emocjonalnej tych wypowiedzi (temperatury, należy dodać, oddanej kolorowymi wykresami) Bereś konkluduje, że Miłosz cierpi na „kompleks powstańca”, którego „przepracowanie” jest przyczyną tej zajadłej nieustępliwości.

„Generalnie Miłosz na pewno uważał, albo było wygodnie mu uważać, że poeci wojenni byli zafascynowani wizją efektownej śmierci i lecieli do niej jak ćmy do ognia, w czym nie sposób im było przeszkodzić, przez co swoich oponentów i sceptyków - jak on - z miejsca wpychali w rolę «Salonu Warszawskiego». Bez wątpienia był to dla niego problem, bo, z jednej strony, miał absolutną pewność swoich racji i patrzył na podziemną młodzież jak na ptactwo

1 Referat został wygłoszony podczas konferencji Miłosz-Miłosz, 11 maja 2011 r. na Uniwersytecie Jagiellońskim w Krakowie. Tekst ma się ukazać w tomie pokonferencyjnym pod redakcją prof. Aleksandra Fiuta.

2 Temat ten wydaje mi się szczególnie ważny teraz, gdyż niedawno - w listopadzie 2011 r. - Okręgowy Sąd Warszawski rozważał rejestrację i, tym samym, legalizację polskiego przedwojennego symbolu faszystowskiego - falangi (ręka z mieczem). Decyzja taka stanowiłaby polityczną, a także psychologiczną legitymizację faszyzmu w kraju, który był przecież jego ofiarą. Połączenie faszyzmu z patriotyzmem: oto zagadka wojennej i niestety dzisiejszej kultury politycznej (niektórych) Polaków. 
prężące szyje przed wielką ucztą, z drugiej - bo miał świadomość, że swoim stanowiskiem ściąga na siebie oskarżenia o brak patriotyzmu, bezideowość, zdradziecki konformizm. Zapewne nie było łatwo chodzić $z$ taką łatką po okupowanej Warszawie, równie trudno było mu z tym w późniejszych dekadach, gdy wchodził w buty Mickiewicza.

Miłosz oczywiście czuł z tego powodu wyrzuty sumienia albo raczej współczucie, ale żeby normalnie funkcjonować, musiał to «przepracować», wyprzeć z siebie. W takim momencie najbardziej przydatne są winy adwersarzy, zwłaszcza tak poważne, jak antysemityzm, a właściwie obojętność na zagładę Żydów (syndrom «biednego chrześcijanina»). Poeta wypominał ją poetom ze «Sztuki i Narodu», bo Borowskiego oraz Baczyńskiego z oczywistych powodów wyłączał, aż do grobowej deski. W ich pismach tylko śladowo (u Bojarskiego i Gajcego) mógt znaleźć dowody intoksykacji ONR-owskiej nienawiści do Żydów, nie miał więc podstaw do uderzenia z całą mocą, co byłoby możliwe, gdyby wiedział, kto pisał komentarze na temat likwidacji getta w «Nowej Polsce». Robił to w sposób pośredni, pokazując po pierwsze, jak dalece polska młodzież już $\mathrm{w}$ dwudziestoleciu dała się omotać prawicowym partiom i uwewnętrzniła ich slogany i rasistowskie teorie, skoro nawet patrząc na mury getta i słysząc odgłosy akcji likwidacyjnej, nie zdołała obudzić w sobie współczucia (jest faktem, że nie ma $w$ ich dorobku ani jednego takiego wiersza, ani artykułu); po drugie, bo należała do organizacji, która «rozwiązanie problemu żydowskiego» miała wyhaftowane na swoich sztandarach, a udawała, że taki problem nie istnieje; po trzecie wreszcie, eksponując, jak mocno była zafascynowana Batalionami Uderzenia, które - zdaniem Miłosza - wsławiły się zabijaniem Żydów ukrywających się w lasach. Mimo ostrych polemik i braku dowodów potwierdzających taką tezę (zob. list Reiffa), poeta jeszcze u końca życia upierał się przy takiej tezie. Trudno już dziś ustalić, czy wynikało to z jego zapiekłej nienawiści do prawicy, czy było to kolejne przeprojektowanie, mające uwolnić go od kompleksu powstańca".

Miłosz krytykował poetów „Sztuki i Narodu” za ich ideologię, którą sam Bereś - mimo wahań i uników - nazywa ultraprawicową (nazwa własna tej konkretnej odmiany ultraprawicowości to faszyzm). W wierszu Przedmowa Miłosz pisał:

\footnotetext{
„Żegnanie epoki brałeś za początek nowej, Natchnienie nienawiści za piękno liryczne, Siłę ślepą za dokonany kształt" [Miłosz 1982: 124].
}

Krytykował młodych faszystów za ich romantyczno-mesjanistyczne, a więc samobójcze, szastanie własnym życiem i wywieranie presji na innych, by stawali do straceńczej walki. Bereś odbiera jego krytyce racjonalną motywację. Za Herbertem deklaruje, że dotyczyła ona całego pokolenia dwudziestolatków, włączając w to Baczyńskiego, który sympatyzował z socjalistami, i Borowskiego, skłaniającego się ku komunizmowi. Za dowód - poza słowami Herberta - Bereś uznaje właśnie wiersz Przedmowa, który rzeczywiście skierowany jest do poetów „Sztuki i Narodu” (choć oczywiście nie tylko), a wezwanie do zmarłych, by nie napastowali żywych, traktuje dosłownie jako zatykanie ust Trzebińskiemu, Gajcemu i Stroińskiemu. Sam zresztą w rozmowie z Miłoszem usiłuje (nieskutecznie) 
zasugerować mu generalizacje dotyczące całego pokolenia3; motywacja ideologiczna krytyki Miłosza nie miałaby wtedy uzasadnienia. W referacie Cierń konspiracji Bereś poszukuje innych niż ideologiczne czy polityczne przyczyny Miłoszowej krytyki:

„Otóż człowiek, zwłaszcza inteligentny i refleksyjny, to taka dziwna istota, która nie zawsze ujawnia publicznie rzeczywiste przyczyny swoich sympatii i idiosynkrazji. Zwłaszcza tych drugich. Bardzo często dorabia skomplikowane uzasadnienia do zwykłych, ludzkich odruchów emocjonalnych dlatego na przykład, bo ktoś został zlekceważony, niedoceniony, dotknięty, obrażony, poniżony. Niejednokrotnie nie ma to nic wspólnego z późniejszymi merytorycznymi argumentami, ponieważ jest rodzajem psychicznej kompensacji. Podam czysto hipotetyczną sytuację. Jest na przykład absolutnie możliwe, że Trzebiński publicznie zakwestionował intelektualny poziom Miłosza (bo tak zrobił w swoim dzienniku), skutkiem czego stały się natarczywe napaści na niego, również po jego śmierci, jako na zdeklarowanego «faszystę». Tego nie wiemy, ale tak być mogło."

Tak więc autor referatu zakłada urazę osobistą, a ponieważ stanowiska antyprawicowego i antyromantycznego nie uznaje za wystarczającą krytykę ideologiczną, nic nie staje na przeszkodzie, by pisać, że powody, jakimi Miłosz się kieruje, to kompleksy i urazy wobec wszystkich bohatersko poległych, a zatem ukrywanie własnego tchórzostwa. Trudno bowiem chodzić z taką łatką komuś, kto „wchodzi w buty Mickiewicza”.

Miłosz wypowiadał się na temat poległych poetów jasno i wielotorowo. Nigdy w ciągu długiego życia nie poparł żadnego elementu ich ideologii, oburzała go ona przed wojną, podczas wojny i po jej zakończeniu. W Zaraz po wojnie (1998 r.) pisał: „Całe szowinistyczne i rasistowskie hecowanie się tuż przed wybuchem wojny, jakby komuś zależało na wpędzeniu Polaków w zbiorowego kręćka, znajdowało dla mnie dalszy ciąg w programowych elukubracjach "Sztuki i Narodu», i bohaterstwo tych chłopców płacących swoim życiem nadawało sprzeciwowi wobec ich upicia się «ideolo» szczególnie bole-

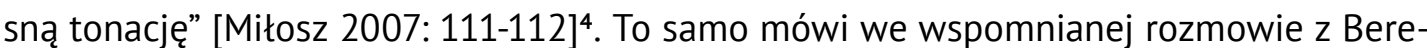
siem: „...chodzi o sprawy osobiste... W każdym razie to ma związek z tym, co pan mówił o wewnętrznym odnowieniu. Żeby odżyć duchowo, musiałem się wyzwolić z pewnego rodzaju romantycznego, mesjanistycznego czucia i myślenia. Musiałem zdobyć się na pewną dozę cynizmu, a nawet brutalności. To była cena wyzwolenia się z «martwej ręki przeszłości». Bardzo przykro i boleśnie to mówić..." [Milosz 2006: 688]. Czytając teksty trzech poetów, których wymieniłam - ich przywoływania krwi, imperium i siły - trudno nie podzielać reakcji Miłosza. W rozmowie z Aleksandrem Fiutem powiedział: „W Warszawie okupacyjnej, tu gdzie było getto, gdzie obok mordowali Żydów i gdzie Polska była

3 Ciekawe byłoby posłuchanie zapisu tej rozmowy, która ukazała się po raz pierwszy w 1997 r., w 12 numerze „Odry” [Miłosz 2006: 688].

4 Dalszy ciąg tej wypowiedzi brzmi następująco: „Kim byliśmy my, jak określaliśmy wobec nich siebie? My, to znaczy starsi, jak Wyka, jak Andrzejewski, jak ja. Rozmowy z tymi młodymi nie udawały się. Byliśmy dla nich «panowie humaniści» i naprawdę słowo «demokracja» brzmiało wtedy starczo, niby bezzębne miamlanie". 
właściwie krajem - no, rzeczywiście, to był anus [podkreślenie za autorem] Europy, tu wtedy marzyć o imperium sięgającym od morza do morza? Wybaczy pan, było $w$ tym ziarno obłędu" [Miłosz 1988: 63-64].

Choć sam nieco kokieteryjnie mówił o swoich przekonaniach, że są to „moje [anty] prawicowe obsesje i fobie" [Miłosz 2007: 9], jego postawa była całkiem spójna i w Polsce, na szczęście, niekiedy podzielana. Przed wojną nie była to jednak postawa większości. „Polska przedwojenna Liga Kolonialna i Morska, w rozrachunku za rozbiory zabiegająca o prawo naszego kraju do części kolonii niemieckich, zgromadziła aż milion członków!" [Tokarska-Bakir 2011]. Nie pozwala to wziąć w nawias ideologii młodych poległych poetów - jak chce Jacek Trznadel - jako jednej wielkiej metafory. Nie wiem zresztą, czy byliby zadowoleni z takiego podważenia powagi i szczerości ich poglądów [Trznadel 1999] $]^{5}$.

Nie chodzi mi jednak o omawianie przekonań tych trzech tak dobrze zapowiadających się poetów. Ani o obronę Baczyńskiego, o którym Miłosz myślał jako o ofierze romantycznej wizji poezji, i to jej przypisywał jego śmierć. Chcę wrócić do głównego tematu kontrowersji, którą symbolicznie uosabiają dwaj wielcy poeci dwudziestowiecznej Polski: Herbert i Miłosz; kontrowersji między: „Bądź wierny/ Idź” [Herbert 1993: 89] a odrzuceniem „przymusu polskiej prawowierności” [Miłosz 2007: 11].

Gdy Miłosz pisał o „szczególnie bolesnej tonacji”, w której wyrażał się jego sprzeciw wobec „ideolo” młodych poetów, chylił głowę przed ich poświęceniem. Ale też wypowiadał się zdecydowanie przeciwko uświęcaniu takiej śmierci, takiej ofiary, takiego poświęcenia. Zagrożeniem dla kultury polskiej jest „szlachetne ojczyźniane myślenie” [Miłosz 2007: 10], które z myśleniem ma niewiele wspólnego, a jest wspólnym przebywaniem W „zaklętym kręgu”, „bezustannym utwierdzaniem się w politycznym banale” [Miłosz 2007: 11], automatyzmem utrzymującym wspólnotę. Te stwierdzenia Miłosza są znane, wielokrotnie powtarzane $w$ rozmaitych wersjach, równie często krytykowane. Miłosz proponuje postawę człowieka, który -zamiast solidarności - każdorazowo ocenia sytuację. Jest możliwe, że poszedłby do walki, gdyby wydała mu się ona mniej beznadziejna lub gdyby miał więcej zaufania do jej przywódców. Ale nie poszedt i jest za to karany do dzisiaj.

Zapytajmy więc, za co jest karany. I o co chodzi w zakazie krytycznego mówienia o zmarłych, a w szczególności poległych? Nie jest to po prostu de mortuis nihil nisi bonum. Polegli to, by tak rzec, wyższa kategoria zmarłych. To ci, którzy zginęli śmiercią gwałtowną, bo stanęli w naszej obronie, swoim życiem zapłacili za to, byśmy mogli żyć. Gotowość pójścia na śmierć jest swoistym kapitałem moralnym. Siłą tym większą, im większe jest zagrożenie życia. Gotowość ta, jak soczewka, ogniskuje przemoc wroga; z jednej strony stanowi tarczę, która, osłaniając innych, przemoc przyjmuje na siebie. Ale przyjmując ją, ten, kto gotów jest poświęcić życie, przekazuje ją dalej jako przymus solidarności, jako

5 Dla zrozumienia postawy poetów „Sztuki i Narodu” najlepsze omówienie stanowi książka Elżbiety Janickiej, Sztuka czy naród? Monografia pisarska Andrzeja Trzebińskiego [Janicka 2006]. 
zobowiązanie do współ-walki. To nie jest kwestia poglądów czy wyboru, lecz presja moralna, siła, która ma mobilizować do działania. Jest to sposób, w jaki ten, kto poświęca życie, zdobywa władzę nad nami - nad tymi, którzy jeszcze żyją.

Nie wszyscy polegli mają ten sam kapitał moralny, nie wszyscy mają nad nami taką samą władzę. Polscy Żydzi - i ci, którzy polegli w walce, i ci, którzy zginęli w komorach gazowych lub rozstrzelani - panują nad wyobraźnią i nad solidarnością rozsianych po świecie Żydów - ale nie Polaków. Nad Polakami, by zacytować Becketta, ich śmierć unosi się jak „te wszystkie głosy, co zmarły./ Brzmiące jakby szum skrzydeł” [Beckett 1985: 63]. Ten szum skrzydeł rozlega się coraz głośniej.

Duchowa władza naszych poległych jest więc proporcjonalna do przemocy, jakiej doświadczyli. Tak przedłuża się straszliwa moc okupanta, który im silniejszy, tym bardziej obecny jest w naszej wyobraźni, myśleniu i nocnych koszmarach. I tym bardziej rządzi odruchami solidarności, rozbijając je u jednych, konsolidując u innych. Ci, których siła okupanta popycha do walki, nie mają się gdzie cofać, bo z drugiej strony napiera na nich solidaryzm: popychani są, by tak rzec, z dwóch stron, a siła okupanta spotyka się w nich z siłą oporu. Gdy siły te zderzają się w człowieku, jedna z nich przeważa i go uśmierca. W rachunku, który Miłosz robi w powieści Zdobycie władzy (Paryż 1953), śmierć - choć przemienia się w kapitał moralny - nie równoważy przemocy okupanta. Tylko uratowane życie - choć po tej walce duchowo poharatane - jest zwycięstwem nad przemocą. I przerywa łańcuch przekazywania opresji.

Z początkiem wojny, jak wiemy, Miłosz pisał wiersze w tradycji romantycznej; określał je później jako „cofnięcie się w szlachetne ojczyźniane myślenie, nie inne niż w wierszach pokolenia warszawskich poetów młodszych ode mnie o lat dziesięć" [Miłosz 2007: 10]. Ten głos, którym poeci wtedy przemawiali, był „niezupełnie ich własny” [Miłosz 2007: 10]. Patriotyczna poezja z okresu wojny posługiwała się zastanym zestawem środków literackich, niejako automatycznie sięgając do dobrze znanego, już przyswojonego słownictwa i obrazowości. Ten niezupełnie własny głos był echem przeszłości, romantycznym głosem poległych i zmarłych. Miłosz wyzwolił się z podległości, z mówienia nieswoim głosem, w roku 1943 i to wyzwolenie miało wpływ - jak pisze - nie tylko na jego poezję, ale także na postępowanie, „bo najwyraźniej chodziło tutaj o akt politycznego wyboru bez niego nie umiałbym pokonać wymagań cnoty” [Miłosz 2007: 10]. Chodziło o „otwarcie się na nieznane losy”, o „radosne wyzwolenie z przymusów obowiązku” [Miłosz 2007: 11]. Odtąd Miłosz pisał inaczej.

Oczywiście takie wyjście poza zaklęty krąg wspólnoty przypłaca się wątpliwościami, wewnętrzną udręką, podwójnością grzechu i kajania się [Miłosz 2007: 12]. Wiersze nie przekazują siły okupanta, nie porażają przemocą, nie pchają ku śmierci. Miłosz nigdy nie był zwolennikiem poświęcenia - nawet tak kochany przez Bojarskiego wiersz Kołysanka był raczej trenem niż zachętą do marszu. Ale treny też przekazują autorytet moralny śmierci, też utrzymują czytelnika w zaklętym kręgu, też zobowiązują do solidarności bez granic. Miłosz jest poetą innej solidarności, solidarności bez militaryzmu, bez 
bezwarunkowego poświęcenia. Poezja, którą pisał od roku 1943, to poezja cywilna. Nie każe, nie karze, nie nawołuje, nie pomstuje. Nie zwraca się do narodu. Mówi o odpowiedzialności moralnej, a ta zawsze należy do jednostki.

Nie oznacza to, że Miłosz popadł w indywidualizm, pacyfizm albo inny tak pogardzany w Polsce kierunek myślowy. Blisko mu było do lewicy, lecz od jej solidaryzmu, nacjonalizmu i militaryzmu był tak samo daleko, jak od rodzimego faszyzmu. Z zaklętego kręgu wyrwał się, by tak powiedzieć, na własną rękę, choć nie mógłby tego zrobić bez ogromnie ważnych przyjaźni z Krońskimi, Andrzejewskim, Wyką, bez wpływu jego partnerki, a potem żony, Janiny Dłuskiej. To jej inteligencja, zimny rozsądek, niepoddawanie się narodowym uniesieniom towarzyszyły Miłoszowi w codziennych wyborach. Tu chcę przypomnieć przytoczony powyżej fragment jego wypowiedzi o pewnej dozie cynizmu i brutalności, której trzeba, by wyzwolić się „z martwej ręki przeszłości”. Jego ataki na obowiązki patriotyczne, jego krytyka poezji naiwnie patriotycznej, odmowa udziału w opłakiwaniu wspólnej niedoli stanowiły brutalne wyłamanie się ze zjednoczonej cierpieniem wspólnoty. Wyjście poza zaklęty krąg wymaga użycia siły, bo przecież jest on utrzymywany przez przemożną siłę dośrodkową, a jego granice nie są zakreślone kredą, tylko pilnowane przez religię, literaturę i obyczaj. Wszystkie donośnie przekazują głosy umarłych, a szczególnie głosy poległych.

Miłosz wycisza, kontestuje głosy poległych, obecnych w jego poezji (jest to ostatecznie poezja polska!), ale nie dominujących jak w poezji Herberta. U Miłosza liczą się przede wszystkim żywi. Brzmi to być może paradoksalnie, bo czyż nie jest on poetą przywracającym nieustannie świat, który odszedt w przeszłość? Miłosz nie zaprasza żywych do połączenia się z poległymi, do uczestnictwa w obłąkanym tańcu śmierci. Przed przymusem uczestnictwa broni się gwałtownym unikiem, używając siły, ale bez aprobowania przemocy. Nie jest pacyfistą, jak już pisałam, ale cywilem z wyboru. W sytuacji przemożnej przemocy przeciwstawiać się jej chce nie śmiercią, a unikiem właśnie, usunięciem się z bezpośredniego pola rażenia. Siła, której się przeciwstawiał, to siła zniszczenia; siła, której używał w tym przeciwstawianiu się, to siła tworzenia. Odmowa wystawiania się na cios po to, by kontynuować to, co ma się do zrobienia, by „ratować co się da”, by pisać [Miłosz 2007: 6]. Miłosz zawsze podkreślał, że jego działalność okupacyjna była częścią oporu ${ }^{6}$. Ten wybór wymagał rozwiązania siłowego, zerwania. Bycie razem jest ciepłe, rozgrzewające; bycie osobno jest zimne. Choć Miłosz mówił o „radosnym” wyzwoleniu się z obowiązku, radość ta trwać mogła chwilę - i odnawiała się, być może, gdy pisał wiersze „swoim głosem”. Poza zaklętym kręgiem panuje wieczny przeciąg.

Skupienie się na wojennych wyborach Miłosza jest ważne, bo spotykają się tutaj podstawowe wątki myślenia o Polsce. Wojna, okupacja, rozbiory wytworzyły model zachowania się polskiego mężczyzny i odstępstwo od normy karane jest bardzo surowo. Podstawową cechą polskiego mężczyzny jest gotowość poświęcenia życia za ojczyznę, nawet - a może przeważnie - wtedy, gdy ofiara ta, by użyć herbertowskiej frazy, jest daremna,

6 Zob. na przykład jego mini-autobiografię w angielsko-języcznej antologii poezji polskiej [Miłosz (wyd.) 1983: II, 73]. 
choć nie bezsensowna. Nie muszę tu chyba wspominać Jarosława Marka Rymkiewicza, który na takiej ofierze osadza samo sedno polskości, wzbudzając ogromny entuzjazm wśród jakże licznych wielbicieli. Paradoksalnie, zgoda na bycie ofiarą wiąże się w tej wersji nierozerwalnie z gotowością użycia siły, a więc przemocy. Bo jest to zgoda na śmierć w walce. W zachowanie polskiego mężczyzny wbudowany jest odruch militarystycznej solidarności; brak tego odruchu nazywany jest tchórzostwem i zdradą. W sytuacji opresji społeczeństwo zamienia się w Spartę, nie ma podziału funkcji społecznych, to „oblężone miasto", z którego raport może wysłać tylko starzec, jak w wierszu Herberta Raport z oblężonego miasta [Herbert 1983: 81-83]. To właśnie jest kontekst, w którym Herbert, a za nim Bereś i inni, przywołują konflikt Miłosza z poetami „Sztuki i Narodu”. Różnice polityczne nie są brane pod uwagę. Sytuacja dorosłego mężczyzny - Miłosz był po trzydziestce - popychanego do samobójczej walki przez patriotycznych dwudziestolatków ma być szczególnie dla Miłosza kompromitująca: on już się przecież jakoś „nażył”, a oni dopiero rozwijali skrzydła. To tak, jakby im zabrał ich młode życie, jakby oni musieli za niego zginąć. Jakby swą śmiercią okupili wstyd jego przejścia do cywila.

Taka wizja obowiązków polskiego mężczyzny zakłada, że jest tylko jeden godny sposób zachowania się, cała reszta to słabość lub „zaprzaństwo”. W sytuacji opresji nie ma wolności wyboru. Decyzje dowództwa powstania warszawskiego należało wykonywać, nawet jeśli się wiedziało, że są bezsensowne pod względem wojskowym i politycznym; a także samobójcze. Śmierć, nagromadzenie śmierci, miało być kartą w przetargu ze światem. Świat (cokolwiek by to miało znaczyć) nie po raz pierwszy wzruszył nad tym ramionami [Janion 1998: 258].

Miłosz wybrat inną drogę. Wbrew ortodoksji, uniesieniom patriotycznym, sile solidarności. Nie zapomniał o odpowiedzialności, odmówił poddania się unii z uświęconym narodem. Wybór był więc możliwy, wolność (w tym wymiarze) ciągle istniała. Zachował siłę sądzenia, a z nią - na tyle, na ile było to możliwe - władzę nad swoim życiem. Dzięki przyjęciu na siebie ciężaru odpowiedzialności pozostał człowiekiem wolnym, a nie rzęsiście potem opłakiwanym „kamieniem rzuconym na szaniec”. Pisząc w wojennej Warszawie Świat (Poema naiwne) [Miłosz 1945], na moment zatrzymał falę przemocy, która miała przepływać przez jego wiersze i posyłać na śmierć jego czytelników. Uwolnił się w ten sposób od zdeterminowania historią, od poddania się presji martwych głosów poległych. 


\section{Bibliografia}

Beckett Samuel, 1985, Czekając na Godota, tłum. i wstęp Antoni Libera, Warszawa: PIW.

Herbert Zbigniew, 1983, Raport z oblężonego miasta, i inne wiersze, Paryż: Instytut Literacki.

Herbert Zbigniew, 1993, Pan Cogito, Wrocław: Wydawnictwo Dolnośląskie.

Janicka Elżbieta, 2006, Sztuka czy naród? Monografia pisarska Andrzeja Trzebińskiego, Kraków: Universitas.

Janion Maria, 1998, Płacz generała, w: taż, Płacz generała. Eseje o wojnie, Warszawa: Sic!, s. XX-XX.

Miłosz Czesław, 1945, Ocalenie, Warszawa : Spółdzielnia Wydawnicza „Czytelnik”.

Miłosz Czesław, 1982, Poezje, t. 1, Paryż: Instytut Literacki.

Miłosz Czesław (wyd.) 1983, Postwar Polish Poetry. An Anthology, wyd. 3: Berkeley: University of California Press.

Miłosz Czesław, 1988, Czesława Miłosz autoportret przekorny. Rozmowy z Aleksandrem Fiutem, Kraków: Wydawnictwo Literackie.

Miłosz Czesław, 2006, Ręka Opatrzności. Z Czesławem Miłoszem rozmawia Stanisław Bereś, w: tenże, Rozmowy polskie 1979-1998, Kraków: Wydawnictwo Literackie, s. 682-700.

Miłosz Czesław, 2007, Zaraz po wojnie, Korespondencja z pisarzami 1945-1950, Kraków: Znak.

Tokarska-Bakir Joanna, 2011, Biało-czerwone i czarne, „Gazeta Wyborcza” z 15 listopada 2011; m.wyborcza.pl/wyborcza/1,105226,10642562.html (dostęp: 20 lipca 2012).

Trznadel Jacek, 1999, Czesław Miłosz: lewy profil, „Arcana”, nr 3 (27); www.jacektrznadel.pl (dostęp: 10 października 2011). 